\title{
Pengembangan Instrumen Performance Assessment Praktikum untuk Mengukur Keterampilan Proses Sains (KPS) Siswa SMP Kelas VIII pada Tema Makananku Kesehatanku
}

\author{
Salma Fajrina*, Lukman Nulhakim, Annisa Novianti Taufik \\ Program Studi Pendidikan IPA, FKIP, Universitas Sultan Ageng Tirtayasa \\ *Email: salmafajrina08@gmail.com
}

DOI: https://doi.org/10.33369/pendipa.6.1.105-112

\begin{abstract}
The instrument of performance assessment for practicum is widely considered as a crucial part in the process of assessment. This study was intended to identify the level of validity of the developed instrument. Research and Development was successfully used as a method in this research with a development model adapted from Sugiyono's development stages as follows: (1) potential problems; (2) data colection; (3) product design; (4) design validation; (5) and design revision. The subject was validators of the performance assessment instrument consisting of two expert teams from a science education lecturer at Faculty of Teacher TrainingUntirta and a science teacher at SMP Negeri 2 Solear. The result of the instrument's validity level was amounted to 93\% with a very valid category. Referring to the results of expert validation, the development of this practicum performance assessment instrument is considered very valid to be used as an alternative practicium assessment to measure Science Process Skills on the theme "My food is my health".
\end{abstract}

Keywords: Performance Assessment Instruments; Science Process Skills; Theme "My Food My Health".

\begin{abstract}
ABSTRAK
Instrumen performance assessment praktikum merupakan bagian penting dalam proses penilaian. Penelitian ini bertujuan untuk mengidentifikasi tingkat kevalidan instrumen yang telah dikembangkan. Metode yang digunakan adalah penelitian dan pengembangan (Research and Development) yang diadaptasi dari model pengembangan menurut Sugiyono melalui tahapan: (1) potensi masalah; (2) pengumpulan data; (3) desain produk; (4) validasi desain; (5) dan revisi desain. Subjek uji coba dalam penelitian ini untuk uji ahli instrumen performance assessment ini adalah dua tim ahli dari dosen pendidikan IPA FKIP Untirta dan salah satu guru IPA di SMP Negeri 2 Solear. Hasil analisis data menunjukkan bahwa tingkat kevalidan instrumen diperoleh nilai rata-rata sebesar 93,3 (kategori sangat valid). Berdasarkan hasil validasi ahli pengembangan instrumen performance assessment praktikum ini dapat digunakan sebagai alternatif penilaian praktikum untuk mengukur Keterampilan Proses Sains (KPS) pada tema makananku kesehatanku.
\end{abstract}

Kata kunci: Instrumen Performance assessment praktikum; Keterampilan Proses Sains; Tema makananku kesehatanku.

\section{PENDAHULUAN}

Pembelajaran IPA memiliki peran yang penting dalam kehidupan. IPA sebagai mata pelajaran pada hakikatnya tidak hanya merupakan kumpulan pengetahuan, akan tetapi juga mengajarkan tentang sikap dan keterampilan. Pada proses pembelajaran IPA secara konvensional yang hanya mengandalkan pada olah pikir siswa yang berarti memperlakukan IPA sebagai kumpulan pengetahuan, siswa akan cenderung hanya menguasai konsep-konsep IPA dengan sedikit, bahkan tanpa diperolehnya keterampilan proses. Sehingga perlu suatu kegiatan dalam pembelajaran yang mampu memberikan 
kesempatan kepada siswa untuk menumbuhkan keterampilan-keterampilannya (Sumarni \& Ngazizah, 2016).

Metode pembelajaran IPA dapat melatih keterampilan siswa dengan menggunakan metode praktikum. Metode praktikum merupakan sarana terbaik yang dapat mengembangkan Keterampilan Proses Sains (KPS) karena aspek Penilaian diperlukan dalam proses praktikum adalah psikomotor dan keterampilan yang dibutuhkan mencakup persiapan praktikum berupa melakukan kegiatan mengamati, mengelompokkan, menafsirkan, memprediksi, hipotesis, keterampilan dalam merencanakan percobaan, menerapkan konsep, dan komunikasi serta kegiatan setelah praktikum yang dapat dilihat dalam bentuk kinerja (Performance). Kegiatan prakktikum memiliki peran dalam pengembangan Keterampilan Proses Sains (KPS) (Nurul, Tamsil, \& Karim, 2019).

Keterampilan Proses Sains termasuk kedalam ranah psikomotorik. Ranah psikomotorik merupakan ranah yang berkaitan dengan keterampilan ataupun kemampuan setelah siswa menerima pengalaman belajar dalam pelajaran IPA. Penilaian aspek psikomotorik dilihat dari kemunculan keterampilan-keterampilan proses sains siswa selama kegiatan praktikum. Keterampilan proses sains perlu dikuasai siswa karena dapat melihat perkembangan kemampuan siswa dalam melakukan suatu aktivitas untuk menemukan sendiri konsep tersebut, siswa dapat lebih mengingat dibandingkan dengang menghafal.

Keterampilan proses sains (KPS) adalah keterampilan siswa dalam mengaplikasikan metode ilmiah yang di butuhkan untuk membuat konsep dan teori pengembangan sebuah konsep yang sudah paten bahkan mengerti dan mengamati kegiatan yang terjadi. (Syaputra, 2016).

Mengidentifikasi sejauh mana pemahaman
siswa pada kompetensi keterampilan, memerlukan sistem penilaian yang sangat tepat untuk menguji (KPS) siswa SMP mata pelajaran IPA Terpadu dalam kegiatan praktikum dapat menggunakan instrumen performance assessment. Performance assesssment merupakan analisis penilaian mengacu dari hasil pengamatan terhadap aktivitas seluruh siswa selama melakukan kegiatan praktikum. Misalnya penilaian menentukan alat dan bahan yang biasa digunakan saat kegiatan praktikum (Suryandari, 2013). Performance assessment sangat sesuai dalam menilai keterampilan. Performance assessment pada prisnipnya Lebih dikenali pada proses keterampilan dan kecakapan untuk merampungkan tugas yang diujikan. Pada performance assessment praktikum Seorang guru wajib menetapkan kriteria kerja yang yang akan di amati secara kompleks. Standar kinerja inilah yang akan menjadi indikator acuan dan indikator penilaian tingkat kualitas kinerja siswa yang dilihatkan dalam praktikum.. Performance assessment praktikum dalam penelitian ini Adalah pacuan penilaian yang berisi standar penilaian yang dapat dikembangkan dengan kombinasi indikator-indikator Keterampilan Proses Sains (KPS).

Selama ini penilaian praktikum masih belum memuaskan. Hal ini dihasilkan dari hasil wawancara dengan seorang guru IPA kelas VIII di SMP Negeri 2 Solear didapatkan bahwa guru IPA sudah menggunakan instrumen performance assessment. Namun pada instrumen penilaian yang digunakan masih secara umum belum spesifik dan belum dilengkapi dengan rubrik penilaian dan kisi-kisi penilaian. Karena kurangnya sarana dan prasarana disekolah ini, maka praktikum dilakukan hanya satu kali dalam satu semester sehingga penilaian yang dilakukan guru tampak kurang mendorong pada pengembangan Keterampilan Proses Sains (KPS) siswa, mesti dilatih bahkan dikembangkan dalam proses pembelajaran IPA karena Keterampilan Proses Sains memiliki peran penting yaitu dapat Meningkatkan daya berpikir, memberi peluang kepada siswa untuk berusaha menemukan suatu penemuan, meningkatkan daya intelektual, serta membantu siswa untuk menciptakan konsep, dan juga guru dalam pembelajaran belum menerapkan pembelajaran secara terpadu.

Berdasarkan permasalahan tersebut perlu adanya solusi untuk memecahkan permasalahakan tersebut yaitu adanya pengembangan instrumen performance assessment praktikum yang diharapkan dapat menjadi solusi bagi guru unruk melakukan penilaian yang efektif pada kegiatan praktikum pembelajaran IPA. Instrumen yang digunakan yaitu instrumen non tes dengan menggunakan lembar observasi. 
Instrumen performance assessment praktikum adalah pedoman untuk penilaian yang basisnya standar-standar penilaian yang dikembangkan dari ketentuan Keterampilan Proses Sains (KPS) menurut Warianto (2011) seperti mengamati (observasi), merencanakan penelitian, meramalkan (prediksi), hipotesis, mengelompokkan (klarifikasi), menafsirkan, menerapkan konsep dan mengkomunikasikan. Adanya pengembangan instrumen performance assessment ini guru akan lebih dimudahkan dalam proses penilaian keterampilan yang ada pada siswa, sebab kriteria penilaian nya jelas. Penilaian dapat dikembangkan sebagai aspek penilaian alternatif pada siswa, hal ini disebabkan oleh keterampilan yang dimiliki siswa tidak pernah sama.

Perangkat performance assessment praktikum ini untuk mmengetahui Keterampilan Proses Sains (KPS), khususnya pada praktikum uji kandungan zat aditif pada makanan dan minuman pada tema makananku kesehatanku. Tema makananku kesehatanku merupakan suatu tema materi pembelajaran dengan menggunakan model keterpaduan connected. Connected adalah model keterpaduan dengan Menerapkan sebuah $\mathrm{KD}$, konsep konsep dasar KD diungkap dan dikombinasikan dengan konsep yang lain (Yesi \& Ana, 2016).

Tema makananku kesehatanku dipilih berdasarkan dari ruanglingkup materi yang digunakan pada indicator atau kegiatan pembelajaran yang berada pada silabus SMP kelas VIII kurikulum 2013 bahwa proses belajar yang yang akan dikembangkan oleh siswa pada KD 3.5 tentang sistem pencernaan pada manusia sebagai KD utama yang bahawasannya pada indikator atau kegiatan pembelajaran yang dilakukan oleh siswa yaitu mengumpulkan informasi tentang penyakit pada sistem pencernaan yang berhubungan dengan makanan yang tidak sehat atau mengandung kandungan zat adiktif. Hal ini juga berintegrasi pada KD 3.6 tentang zat adiktif dan zat aditif sebagai KD pendukung yaitu mengidentifikasi zat-zat adiktif yang terdapat pada makanan atau minuman melalui percobaan. Hal ini sesuai dengan praktikum yang akan digunakan pada tema makananku kesehatanku dan KD 4.6 tentang pembuatan laporan praktikum sederhana tentang zat aditif. Materi-materi tersebut diperlukan adanya pengalaman secara langsung siswa berupa praktikum untuk menemukan fakta dan memecahkan masalah. Praktikum yang dilakukan yaitu praktikum uji kandungan zat adiktif murni dan buatan yang berada dalam makanan dan minuman yang berada dilingkungan sekitar siswa yang berhubungan dengan sistem pencernaan pada manusia.

Berdasarkan penelitian dan pengembangan maka permasalahan yang diuraikan pada Penelitian ini yaitu : Bagaimana tingkat kevalidan instrumen performance assessment praktikum yang dikembangkan untuk mengukur Keterampilan Proses Sains (KPS) siswa SMP kelas VIII pada tema makananku kesehatanku?

\section{METODE PENELITIAN}

Pengembangan instrumen performance assessment Praktikum ini mengaplikasikan metode penelitian dan teknik inovasi (research and development). Penelitian dan inovasi merubah sebuah proses atau metode yang diaplikasikan untuk menemukan validitas suatu produk sehingga menghasilkan produk tertentu (Sugiyono, 2013).

Penelitian diaplikasikan pada semester ganjil yakni pada bulan Agustus 2020 - Januari 2021. Dalam proses penelitian terdapat dua subject yakni subjek yang penelitian dan subjek yang uji coba. Subjek yang akan diteliti dikembangkan adalah instrumen performance assessment praktikum untuk mengukur tingkat Keterampilan Proses Sains (KPS). Sementara subjek uji coba untuk uji ahli instrumen performance assessment merupakan dua tim ahli dari dosen pendidikan IPA FKIP Untirta yang ahli dalam metode Instrumen penilaian dengan jenjang minimal S2 serta 1 guru IPA di SMPN 2 Solear yang ahli di bidangnya dengan jenjang pendidikan terakhir S2.

Desain Penilaian yang diterapkan adalah pengembangan yang dengan sebuah model pengembangan dari Sugiyono akan tetapi tidak semua langkah pengembangan diterapkan, hal ini dikarenakan kondisi sekolah yang masih melakukan pembelajaran daring dan tidak memungkinkan untuk melakukan kegitan praktikum dikelas. Langkah-langkah pada penelitian ini yaitu :

\section{Tahap Potensi dan Masalah}


Analisis potensi dan masalah ini dilangsungkan di SMP Negeri 2 Solear dengan menggunakan teknik wawancara pada salah satu guru IPA kelas VII. Dari wawancara tersebut didapatkan bahwa guru disekolah tersebut sudah menerapkan instrumen performance assessment praktikum akan tetapi pada penilaian tersebut masih secara umum dan belum disertakan dengan rubrik penilaian dan kurang mengasah kemampuan dalam Keterampilan Proses Sains (KPS). Tahap ini pun melakukan analisis terhadap materi dengan mengidentifikasi isi materi mengenai tema makananku kesehatanku yang sesuai dengan (KI) dan (KD) pada kurikulum 2013.

\section{Tahap Pengumpulan Data}

Informasi diperoleh dengan kajian pustaka dokumen terkait dari berbagai buku atau jurnal sesuai dengan instrumen yang akan dikembangkan, serta data yang dikumpulkan pada penelitian inidyaitu wawancara mengenai ketersediaan instrumen performance assessment dalam kegiatan praktikum serta anget yang digunakan untuk penilaian kevalidan pada instrumen performance assessment praktikum yang telah dikembangkan.

Hasil penelitian dan pegembangan ini mendapatkan data yang kemudian akan dianalisis dengan menggunakan deskriptif kuantitatif.

\section{Tahap Desain Produk}

Tahap ini dilakukan penyusunan draf awal hingga menjadi produk awal berupa instrumen performance assessment. Instrumen yang dikembangkan terdiri dari beberapa tahapan yaitu diawali dengan menentukan KD yang akan digunaan dan sangat dekat dengan siswa, sehingga mampu melatih KPS dari lingkungan sekitar. Setelah itu merumuskan indikator KPS yang akan diukur, penyusunan tugas kinerja siswa, penyusunan kisi-kisi, serta membuat rubrik instrumen performance assessment praktikum. Setelah dibuat draf awal yang dikembangkan melalui instrumen performance assessment praktek guna mengukur Keterampilan Proses Sains (KPS) dibuat kemudian selanjutnya di validasi ahli.

\section{Tahap Validasi Desain}

Validasi dikerjakan oleh seorang validator yang memiliki tujuan agar memperoleh pengakuan dan penilaian. Lembar angket validasi ahli yang berisikan yakni aspek isi, aspek disain, aspek kesesuaian, dan aspek bahasa. Analisis hasil data validasi ahli dikerjakan dengan analisis deskriptif kuantitatif menggunakan penafsiran kriteria instrumen bergantung pada skala dan jumlah butir penilaiannya (Madapi, 2012). perlengkapan yang melengkapi berupa lembar angket validasi dengan mengaplikasikan Skala Likert (Sugiyono, 2013). Berikut ini merupakan penetapan skor untuk penilaian kevalidan instrumen performance assessment untuk mengukur KPS dapat dilhat pada Tabel 1.

Tabel 1. Kriterian Penilaian Tingkat Kevalidan Instrumen Performance Assessment Praktikum untuk Mengukur Keterampilan Proses Sains (KPS)

\begin{tabular}{ccc}
\hline No & Kategori Penilaian & Skor \\
\hline 1 & Sangat Baik & 5 \\
2 & Baik & 4 \\
3 & Sedang & 3 \\
4 & Buruk & 2 \\
5 & Buruk Sekali & 1 \\
\hline
\end{tabular}

Data yang didapatkan dari proses analisis angket oleh uji ahli akan dihitung skor rata-rata pada setiap aspek kriteria penilaian untuk memperoleh hasil akhir kevalidan instrumen performance assessment praktikum untuk mengukur KPS, proses perhitungan dihitung dengan menggunakan rumus sebagai berikut:

$$
N P \quad \frac{R}{S M} \times 100 \%
$$

(Purwanto, 2009)

Keterangan :

NP : Nilai persen yang dicari atau diharapkan

R : Skor mentah yang diperoleh

SM : Skor maksimal ideal

$100 \%$ : Bilangan tetap

Adapun persentase skor jawaban setiap pernyataan untuk menentukan tingkat kevalidan instrumen performance assessment praktikum 
menurut (Arikunto, 2009) dapat dilihat pada Tabel 2.

Tabel 2. Kategori presentasi hasil kevalidan instrumen performance assessment praktikum untuk mengukur KPS pada tema makananku kesehatanku

\begin{tabular}{ll}
\hline Persentase $(\%)$ & Kategori Kevalidan \\
\hline$>20 \%$ & Sangat kurang valid \\
$21 \%-40 \%$ & Kurang valid \\
$41 \%-60 \%$ & Cukup valid \\
$61 \%-80 \%$ & Valid \\
$81 \%-100 \%$ & Sangat valid \\
\hline
\end{tabular}

\section{Tahap Revisi Desain}

Pada bagian ini terdapat revisi dan hasil validasi dari anggota tim ahli. Revisi dikerjakan dengan menguji kritik dan saran lewat sebuah metode penilaian. proses revisi akan rampung setelah produk yang dianalisis sudah dikatakan valid dan dapat aplikasikan dalam proses penilaian praktikum siswa.

\section{HASIL DAN PEMBAHASAN}

Penelitian pengembangan ini menghasilkan produk berupa instrumen performance ssessment yang diaplikasikan untuk mengukur Keterampilan Proses Sains (KPS). Instrumen dikatakan valid apabila memiliki skor rata-rata hasil validasi oleh validator (ahli) mencapai kategori sangat valid atau valid (Khotimah, Endang, \& Nurhayati, 2017).

Tingkat kevalidan instrumen tersebut dapat diperoleh dari hasil penilaian pada lembar angket validasi yang terdiri dari empat aspek berdasarkan (Erick, Rayandra, \& Bambang, 2015) yang telah dimodifikasi yaitu aspek kevalidan isi, aspek konstruksi, aspek kesesuaian, dan aspek bahasa. Produk yang telah berkembang dan divalidasi oleh validator untuk mengidentifikasi tingkat kevalidan dari produk tersebut. Hasil validasi produk dapat dilihat pada Gambar 1.

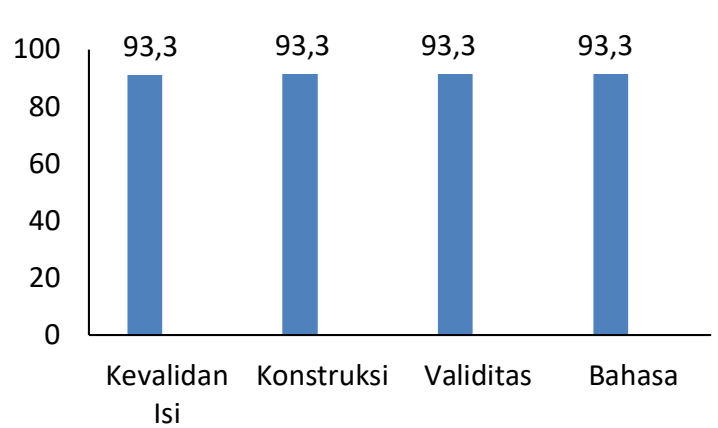

Gambar 1. Hasil Rata-Rata Uji Kevalidan Instrumen Performance assessment Praktikum Untuk Mengukur Keterampilan Proses Sains (KPS) pada Tema Makananku Kesehatanku yang dilakukan oleh 3 Validator (Ahli)

Berikut pemaparan perolehan tingkat kevalidan dari masing-masing perspektif yang digunakan untuk menilai instrumen performance assessment untuk mengukur (KPS) pada tema makananku kesehatanku.

\section{Aspek Kevalidan Isi}

Aspek kevalidan isi ditunjukkan untuk mengetahui kualitas instrumen performance assessment. Validan isi instrumen ini bertujuan untuk mengukur sejauh mana butir-butir dalam instrumen ini mencakup isi yaitu apakah butirbutir penilaian dalam instrumen yang dikembangkan telah mencerminkan indikator dari aspek/variabel penilaian yang hendak dinilai dalam penelitian. Instrumen performance assessment yang dikembangkan dinilai dan diberi saran serta masukan perbaikan oleh ahli (Sudrajat, Permanasari, \& Zainul, 2011). Hasil penilaian terhadap kualitas instrumen performance assessment praktikum pada aspek kevalidan isi memperoleh persentase 93,3\% dengan kategori sangat valid. Ini berarti instrumen performance assessment praktikum valid dalam aspek kevalidan isi. Hal ini berdasarkan sudah terpenuhinya standart kevalidan isi yang mencakup, pernyataan untuk kesesuaian instrumen performance assessment praktikum dengan KD pada kurikulum 2013, terdapat petunjuk pengisian yang mudah dipahami dan jelas, mencantumkan kisi-kisi penilaian dan kriteria penilaian pada instrumen performance assessment praktikum disajikan dengan lengkap. 
Kisi-kisi merupakan deskripsi kompetensi materi yang diujikan. Petunjuk pengisian tentang instrumen performancce assessment praktikum untuk mengukur KPS bertujuan untuk memberikan informasi dalam menggunakan instrumen performance assessment praktikum untuk mengukur KPS sehingga memudahkan guru dalam memahami isi instrumen yang dikembangkan (Sunarti dan Selly, 2013)

\section{Aspek Konstruksi}

Aspek konstruksi ditunjukan untuk mengetahui instrumen yang dikembangkan dapat melengkapi persyaratan teknis yang tepat dengan instrumen sesuai dan akurat. Hasil penilaian terhadap kualitas instrumen performance assessment praktikum pada aspek konstruksi memperoleh persentase 93,3\% dengan kriteria sangat valid. Hal ini menandakan instrumen performance assessment praktikum hasil pengembangan dianggap sudah valid untuk aspek konstruksi. Hal ini mengacu pada sudah teripenuhinya standar aspek konstruksi yang terbagi, instrumen performance assessment praktikum memiliki ketepatan dengan metode dan teknik penilaian yang diaplikasikan, instrumen memiliki kesamaan dengan kerangka kegiatan praktikum uji kandungan zat aditif pada makanan dan minuman, instrumen sudah memiliki sistem penskoran yang akurat dan sesuai, instrumen dirancang secara terukur dan sistematis dengan acuan kriteria penilaian aspek KPS dan indikator KPS, instrumen sudah memiliki rubrik penilaian yang sesuai.

Rubrik penilaian berisi kriteria penilaian siswa, indikator KPS dan prosedur kerja siswa dalam menentukan tingkat pencapaian kompetensi KPS siswa. Untuk menentukan tinggi rendahnya kinerja yang dimaksud dapat menggunakan alat skala berupa rubrik untuk memberikan skor-skor tiap kriteria yang sudah ditentukan (Ngadip, 2016). Instrumen performance assessment yang dikembangkan juga dilengkapi dengan pedoman peskoran yang berfungsi sebagai acuan dalam menentukan skor yang diperoleh siswa sesuai dengan rumus atau tata cara penilaian yang ditetapkan (Sumaryanta, 2015)

\section{Aspek Validitas (Kesesuaian)}

Standar validitas ditunjukan untuk menemukan apakah produk sudah dikembangkan sudah memenuhi indikator penilaian KPS atau belum. Berdasarkan Gambar 1 dapat diketahui bahwa hasil penilaian oleh validator terhadap aspek validitas mendapatkan persentase 93,3\% yang termasuk kedalam kategori valid. Kriteria penilaian aspek validitas adalah mengukut KPS siswa dengan 8 indikator yaitu memperhatikan, menyatukan, mengartikan, memprediksi, hipotesis, menyusun rencana penelitian, menerapkan konsep dan berkomunikasi (Warianto, 2011).

Validator (ahli) menilai bahwa instrumen performance assessment kegiatan praktik untuk mengkaji Keterampilan Proses Sains (KPS) pada tema makananku kesehatanku yang dikembangkan telah dapat digunakan untuk mengukur KPS. Menurut Permendikbud No 20 Tahun 2007 bahwa penilaian beracu pada standar kompetensi/indikator yang sudah di standarisasikan. Pernyataan pada instrumen harus dapat memuat kriteria penilaian KPS yang terukur, sehingga penilaian yang diperoleh bersifat akuntabel. Teknik observasi berupa lembar observasi KPS yang digunakan oleh guru. Lembar observasi dilakukan dengan cara memberi tanda checlist $(\checkmark)$ sesuai dengan pernyataan pada lembar observasi performance assesssment praktikum untuk mengukur KPS pada tema makananku kesehatanku.

\section{Aspek Bahasa}

Aspek bahasa ditunjukkan untuk mengetahui kevalidan dan kesesuaian bahasa yang digunakan pada produk yang dikembangkan. Aspek bahasa menghasilkan nilai standar rata-rata $93 \%$ yang termasuk dalam kriteria sangat valid. Meskipun instrumen performance assessment yang diuraikan sudah dapat digunakan sebagai perlengapan penilaian, namun ada beberapa saran masukan dari ahli untuk menyempurnakan instrumen performance assessment praktikum untuk mengukur KPS yang dikembangkan.

Masukan dan saran yang diberikan yaitu konsistensi dalam penggunaan bahasa. Kevalidan perlengapan dari sudut pandang bahasa wajib memenuhi 3 aspek yaitu bahasa komunikatif yang tepat dengan tingkatan pendidikan, 
memakai bahasa Indonesia yang standar dan tidak menggunakan bahasa lokal atau tabu (Matondang, 2010). Hal ini sudah sesuai dengan aspek bahasa pada instrumen performance assessment praktikum untuk mengukur (KPS) yang dikembangkan.

\section{KESIMPULAN}

Berdasarkan hasil penelitian dan pembahasan, maka dapat disimpulkan bahwa tingkat kevalidan pada pengembangan instrumen performance assessment praktikum untuk mengukur (KPS) siswa SMP kelas VIII pada tema makananku kesehatanku memperoleh hasil dengan predikat rata-rata secara keseluruhan sebesar 93,3\% dengan kategori "sangat valid". Berdasarkan hasil validasi ahli tersebut maka instrumen performance assessment yang dikembangkan sangat valid untuk diaplikasikan sebagai alternatif penilaian praktikum untuk menilai (KPS) tema makananku kesehatanku.

\section{DAFTAR PUSTAKA}

Arikunto, S. (2009). Dasar-dasar Evaluasi Pendidikan (A. Bumi, ed.). Jakarta.

Erick, S., Rayandra, A., \& Bambang, H. (2015). Pengembangan Instrumen Evaluasi pada Praktikum Uji Enzim Katalase di SMA Negeri Titian Teras Muaro Jambi. EduSains, 4(2), 1-8.

Khotimah, K., Endang, S., \& Nurhayati, S. (2017). Pengembangan Instrumen Performance Assessment Berbasis Pembelajaran Kontekstual untuk Mengukur Keterampilan Laboratorium Siswa. Chemistry in Education, 6(2), 64-69.

Madapi, D. (2012). Pengukuran Penilaian dan Evaluasi Pendidikan (Muha Medik). Yogyakarta.

Matondang, Z. (2010). Penyusunan Instrumen/Tes Standar.

Ngadip. (2016). Konsep dan Jenis Penilaian Autentik. E-Jurnal Dinas Pendidikan, 1, 113.
Nurul, O., Tamsil, M., \& Karim, H. (2019). Pengembangan Instrumen Asesmen Kinerja Praktikum Biologi MA Pesantren Madinah Makassar. 1-8.

Purwanto, M. N. (2009). Prinsip-Prinsip dan Teknik Evaluasi Pengajaran (R. Remaja, ed.). Bandung.

Sudrajat, A., Permanasari, A., \& Zainul, A. (2011). Pengembangan Rubrik Asesmen Kinerja untuk Mengukur Kompetensi Mahasiswa Melakukan Praktikum Kimia Analisis Volumetri. Jurnal Chemica, 12(1), $1-8$.

Sugiyono. (2013). Metode Penelitian: Alfabeta Slavin E. Robert.2010. Cooperating Learning (Teori, Riset dan Prakti) (C. ALFABETA, ed.). Bandung.

Sumarni, T., \& Ngazizah, N. (2016). Pengembangan Penilaian Kinerja Praktikum Berbasis Generik Sains untuk Mengukur Keterampilan Peserta Didik SMA Kelas X. Jurnal Radiasi, 9(1), 19-23.

Sumaryanta. (2015). Pedoman penskoran. Indonesian Digital Journal of Mathematic and Education, 2(3), 181-190.

Suryandari, E. T. (2013). Performance Assessment Sebagai Instrumen Penilaian Untuk Meningkatkan Ketrampulan Proses Pada Praktikum Kimia Dasar Di Tadris Kimia. Jurnal Phenomenon, 3(2), 19-34.

Syaputra, A. (2016). Analisis Perkembangan Aspek Keterampilan Proses Sains Kimia Siswa Melalui Pembelajaran Berbasis Literasi Sains Dan Teknologi Di SMA Muhammadiyah 11 Padangsidimpuan. Jurnal Eksakta, 2(1), 49-53.

Warianto. (2011). Keterampilan Proses Sains (P. M. G. Kencana, ed.). Jakarta. 
Yesi, M., \& Ana, W. (2016). Penerapan Model

Pembelajaran Brain Based Learning

Menggunakan Pembelajaran IPA Terpadu

Tipe Webbed dan Connected Pada Materi

Pemanasan Global untuk Meningkatkan

Penguasaan Konsep dan KPS. Jurnal

Edusains, 8(2), 128-135. 